\title{
EUROINTEGRATION PROCESSES IN THE AGRARIAN SECTOR OF THE BULGARIAN ECONOMY AND THEIR IMPACTS ON INVESTING IN AGROINDUSTRIAL COMPLEX
}

\author{
M. D. Georgieva \\ (National Transport University, Kyiv)
}

The article examines the position of the agro-industrial complex of Bulgaria and summarizes the advantages and disadvantages of Ukraine's participation in the European integration processes and outlines the directions of further agrarian policy. The current state and main tendencies of functioning of the agro-industrial complex of Bulgaria are determined and the historical conditions and factors of development of the agrarian sector of the Bulgarian economy are investigated. The analysis of the agroindustrial complex activity by the volume of production and sale of the main types of food products in different regions of Bulgaria in the process of European integration of the Bulgarian economy.

Key words: agriculture, agrarian sphere, European integration processes, state regulation, state support, agricultural commodity production, cooperation, Bulgaria, European Union.

М. Д. Георгієва. Свроінтеграційні процеси в аграрному секторі економіки Болгарії та їхній вплив на інвестування в агропромисловий комплекс

У статті розглянуто сучасний стан і основні напрями розвитку агропромислового комплексу (дала - АПК) та окреслено основні чинники та фактори розвитку аграрної сфери економіки Болгарії. Визначено основні вектори діяльності АПК за обсягом виробництва та реалізації основних видів продовольчих товарів у різних регіонах Болгарії у 2007-2014 роках, а також передумови і шляхи для залучення продукиії АПК Болгарії на європейські ринки. Окреслено головні проблеми формування європейської аграрної моделі. Дослідженодочільністьзалученняокремихгруптоварівіз поглядуконкурентоспроможності в контексті європейської інтеграиії. Пропонується створити та запровадити систему агрологістичного комплексу. Надається історична та політико-політична класифікація заходів державної підтримки сільського господарства для забезпечення ефективної діяльності аграрного сектору економіки Болгарії. Очінено можливості створення аграрних спеціалізованих районів на регіональному, національному та міжнародному рівнях.

Агропромисловий комплекс був і залишається пріоритетним сектором болгарської економіки, і найближчим часом стратегія виходу на ринок СС буде важливою для майбутнього розвитку. ЄС - ие величезний ринок збуту. При иьому інтеграчія на такий ринок має як переваги, так і недоліки. Одне з найскладніших питань у цьому контексті адаптачія болгарської економіки до умов і вимог Європейського Союзу.

У статті відображено результати дослідження еволючії САР ЄС, проблеми їі сучасного реформування у складних умовах спаду європейської економіки. Автор намагається проаналізувати основні тендениії модернізащиї інвестиційної політики ЄС щодо сільського господарства Болгарії та визначити фактори, що впливають на євроекономічну інтеграцію аграрного сектору економіки Болгарії. Дослідження використовувало системний підхід, який включав загальнонаукові (діалектичний, наукову абстракиію, індукиію та дедукиію, аналіз і синтез, закони логіки) та спеціальні історичні (історико-економічний, порівняльний

(C) M. D. Georgieva, 2019 
аналіз, статистичний, критичний) методи дослідження. Визначено фактори ризику та перспективи адаптації болгарського сектору до умов ЄС і необхідність активізувати розвиток болгарського сільськогосподарського сектору.

Ключові слова: сільське господарство, аграрна сфера, євроінтеграчійні процеси, державне регулювання, державна підтримка, аграрне товаровиробництво, співробітництво, Болгарія, Європейський Союз.

Problem statement. The development of the modern world is evolving through the liberalization and globalization of the economy: it is an objective and irreversible process. The geographical and political location of Bulgaria is such that it is close to both the countries of the European Union (EU) and the countries of the former Soviet Union. Bulgaria is a transit country between East and West. During the beginning of the XXI century. Bulgaria faces the problem of defining an integrated development strategy.

Bulgaria has embarked on the path of an associate EU member during one of the most difficult periods of its history. With a view to overcoming the systemic crisis, consolidating the country, confronting external aggression and overcoming its consequences, it is never more important to ensure the maximum positive effect of European integration for the development of Bulgarian society.

The European choice was to become the basis for nation-wide unity based on the idea of modernizing the country. Renewal of guarantees to all, without exception, residents of Bulgaria of their constitutional rights in full - the first extremely serious examination of Bulgaria as an associated EU member.

European integration processes have become an integral feature and direction of development of the agrarian sector of the Bulgarian economy. In this regard, it was necessary to develop an agricultural policy that would take into account the socioeconomic, environmental, demographic and other components, and would be based on familiarization, study and practical application of agricultural experience in foreign countries, which caused a naturally increased interest. Of paramount importance is the interdependent activities of the state and business entities, aimed at ensuring food security, in particular at the regional level, and an integrated approach in planning territorial development.

Therefore, today it is necessary to study the main stages of Bulgaria's European integration processes and to evaluate their impact on agricultural development. This will reveal threats related to the implementation of European integration intentions, changes in foreign policy, customs legislation, etc.

Analysis of recent research and publications. Significant contribution to the study of the problems of Bulgaria-EU relations, the issue of agriculture development in the conditions of globalization processes and analysis of European integration problems of Bulgaria, including the peculiarities of the development of the agriculture sector, made by such domestic and Bulgarian scientists as B. Ivanov, D. Vachkov, H. Bashev, 
M. Atanasova1. The results obtained allow them to form a knowledge system for the European integration perspective of the Bulgarian agrarian sector of the economy.

At the same time, the authors do not sufficiently raise the issue of the impact of transformations of foreign trade in agricultural products in the new conditions of foreign economic policy of the state.

The purpose of the article. Identify the main benefits and negative consequences for agricultural producers of Bulgaria's accession to the EU and assess their impact on the development of the Bulgarian agricultural sector.

Presenting main material. Adaptation of the agrarian sector of the Bulgarian economy to the conditions and requirements of the European Union is a complex and controversial process. The development of integration at the European level is a modern sign of progressive changes in agriculture and a relatively new area of research in national historical science. European landmarks provide the agricultural sector with an appropriate vector of development and open up new opportunities for agricultural revival, creating additional comparative advantages in the agri-food market in the context of the globalization of the economy and the global food crisis.

A major step in deepening trade relations between Bulgaria and the EU was to become a Free Trade Area Agreement (FTA), which would help bring the Bulgarian agricultural sector closer to European standards, adapt it to the EU Common Agricultural Policy (EU Common Agrarian Policy) and enlargement market of new EU member states. In order to successfully solve the problems of European integration, the agricultural sector of the Bulgarian economy had sufficient prerequisites: rich natural resource and export potential, considerable human capital, gradually increasing investment attractiveness, preserved lifestyle of agriculture and centuries-old traditions of agriculture.

However, in the context of the economic crisis, it is extremely important to analyze the opportunities and the likelihood of the challenges that European integration processes entail for the domestic agrarian sector of the economy. The level of readiness of the Bulgarian agrarian sector for the conditions of European integration in comparison with the CEE countries that joined the EU in the last wave of enlargement, shows that similar transformational transformations of Bulgaria did not take place, the European integration process in Bulgaria was at an early stage research into the history and theory of integration in the agricultural sphere. This is due to the specificity of agriculture as an industry, its strategic importance for the Bulgarian economy, and the need to adapt it to the requirements of the reformed EU CAP.

\footnotetext{
${ }^{1}$ Анастасова М. Миграционните процеси на населението в Р. България при прехода към пазарна икономика. София : Издателство на институт по икономика на селското стопанство, 2015. 830 с.

Башев Х. Ефекти от прилагане на европейски политики вїрху земеделските стопанства в Р. България. София : ИАИ, 2018. $378 \mathrm{c.}$

Вачков Д. Българският външен дълг: Банкрутът на комунистическата икономика. София : Институт за изследване на близкото минало, 2009. 456 с.

Вачков Д. НРБ от началото до края. София : Институт за изследване на близкото минало, 2011. 480 с. Иванов Б. Устойчивост в земеделието. София : Авангард Прима, 2009. 230 с.
} 


\section{Проблеми сучасності}

The development of integration at European level is a modern sign of progressive changes in agriculture and a relatively new area of research in domestic agrarian science. European benchmarks provide the agricultural sector with an appropriate vector of development and open up new opportunities for the revival of agriculture, creating additional comparative advantages in the agri-food market in the context of economic globalization. A major step forward in terms of deepening trade relations between Bulgaria and the EU should be the Free Trade Area Agreement (FTA), which will help bring the Bulgarian agricultural sector closer to European standards, adapt it to the EU Common Agricultural Policy and expand its presence in the global market. EU members.

According to the Statistical Office of Bulgaria, in 2013, foreign direct investment in agriculture, forestry and fisheries increased by $15 \%$, while in the economy as a whole by only $5 \%$, amounting to $\$ 839.3$ million. USA ${ }^{2}$.

The most attractive for foreign investors is the agriculture of Plovdiv and Veliko Tarnovo regions. About half $(47.8 \%)$ of the sector's investments were received in these regions, including Plovdiv attracted $20 \%$, Plovdiv region $-15.8 \%$, and Veliko Tarnovo region $-12 \%$.

Agricultural producers in the Sofia region attracted 6.3\%, Rousse $-5.7 \%$, Gabrovo- $5.0 \%$ of foreign investments. The volume of foreign direct investment attracted to the agricultural sector of Shumen and Lovech regions is 3.7\% and 3.5\% respectively. Burgas and Stara Zagora attracted $3.1 \%$ each $^{3}$.

The rest of the Bulgarian regions accounted for only about $22 \%$ of foreign investment.

Cyprus was the main investor country, from which \$376.2 million came. USA. In second place is Germany, which invested \$ 71.5 million in the agricultural sector of Bulgaria. USA. It is followed by Denmark, whose share is close to $-\$ 66.2$ million. USA.

More than half of the investment $-56 \%$ - goes to crop production, mainly for the cultivation of annual and biennial crops, in particular, vegetables and berries. In 2013, $34 \%$ of FDI was channeled into livestock development ${ }^{4}$.

It should be noted that in the structure of foreign investments the EU countries remained the main investor in the Bulgarian economy. Therefore, the country's integration into the EU was a significant step forward, bearing both positive developments and serious challenges, including the need to ensure national interest in the field of food security and the competitiveness of the Bulgarian agricultural producer.

Thus, according to pro-European experts, the implementation of the FTA between the EU and Bulgaria can bring considerable benefits to the agricultural sector, in particular as a result of:

- growth of Bulgarian exports to the EU;

- increasing access to third country markets through harmonization of standards with the EU;

\footnotetext{
${ }^{2}$ Русчева Д. Продоволствените ресурси на България при осъществяване на Общата селскостопанска политика на ЕС. София : Унив. изд. «Св. Климент Охридски”, 2010. С. 79.

${ }^{3}$ Тютюнджиев И. Стопанска история на България. София : Ровита, 2011. С. 113.

${ }^{4}$ Натан И. Икономика на България. София : Наука и изкуство, 2013. С. 106.
} 
- improvement of the investment climate as a result of the adaptation of national legislation to EU rules and regulations;

- abolishing subsidies on agricultural exports from the EU to Bulgaria;

- gradual increase of quotas for export from Bulgaria to the EU of certain types of agricultural products.

The obvious tests Bulgaria has experienced since joining the EU are:

- increased competition in the internal market, especially in the short term, by eliminating tariffs and reducing non-tariff barriers;

- restricting the access of Bulgarian goods to the European markets under the pretext of their non-compliance with European standards and certificates;

- withdrawal from the free trade regime of almost 400 commodity positions, mainly agricultural commodities, the liberalization of which exports to the EU markets would be most beneficial for Bulgaria;

- the introduction by the EU of a discriminatory system of tariff quotas for Bulgaria at a very low level (for most types of products these quotas represent less than $6 \%$ of the EU market for these products (fruit, vegetables, meat, etc.);

- the abolition of the export duty on tomatoes, which could deprive Bulgarian processing plants of raw materials;

- maintaining a multi-billion-dollar agricultural sector subsidy to the EU, rendering Bulgarian products exported to the EU and third countries uncompetitive ${ }^{5}$.

In order to successfully solve the problems of European integration, the agricultural sector of the Bulgarian economy had sufficient prerequisites: rich natural resource and export potential, significant human capital, gradually increasing investment attractiveness, preserved lifestyle of rural life and centuries-old traditions of farming. In this context, research and scientific reflection on the experience of shaping the European agricultural model will help to carry out structural reforms in the field of agriculture and increase the level of competitiveness of agri-food products in the European and world markets.

In addition, there is now a need to improve the quality of information support in agriculture due to the fact that the agreement with the EU provided for serious adjustments to regulatory practices in Bulgaria, in particular in the areas of competition, state aid, public procurement, sanitary and phytosanitary measures, technical regulation, protection of intellectual property rights, ensuring sustainable development, etc.

The process of updating and improving the legislation in the field of state support to agriculture should be intensified, taking into account Chapter 17, Section 5, of the said Agreement, which deals with agriculture and rural development ${ }^{6}$.

A thorough analysis of the key provisions of the Agreement shows that the main threats to farmers in the future may be: increased competition in the internal market, especially in

\footnotetext{
${ }^{5}$ Назаренко В.И. Аграрная политика Европейского Союза / Институт Европы РАН. Москва : ООО «Маркет ДС Корпорейшн», 2004. С. 226.

${ }^{6}$ Маслоу Е. Мотивация и личность. София : Кибея, 2001. С. 170.
} 
the short term, restricting the access of Bulgarian producers to European markets due to non-compliance with quality standards.

Since the budget support for agriculture in the EU is $45 \%$ of the gross value of the product sector, and in Bulgaria - only $6 \%$, according to many scientists, forecasts for ensuring the competitiveness of domestic products are rather disappointing?

The necessity of implementation of these norms will significantly affect the content of the agrarian-legal institute of state support of agriculture and needs in the near future the development and adoption of special programs. Yes, the suggestion of experts on the adoption of the Agribusiness Adaptation Program to work in the conditions of the common European market is reasonable ${ }^{8}$.

Public authorities, together with Bulgarian producers, should make considerable efforts to gradually approximate EU rules and standards in the field of trade in agricultural products and related industries, such as standards and rules of conformity assessment, sanitary and phytosanitary rules, intellectual property rights, and intellectual property rights. and competition required to comply with trade-related energy aspects, including such as investment, transit and transport forging.

It should be noted that Bulgaria could also become a "vegetable basket" of Europe, and in the production of products that will not directly compete with producers of France, Spain, Italy, etc., and will promote the EU's self-sufficiency of the main agricultural products and guarantee EU food security.

By deepening co-operation with the EU, Bulgaria has received new incentives to develop the internal market and deepen the economic specialization of the regions. Agricultural production with its updated structure was directed to domestic consumption. However, the expansion of foreign economic prospects of Bulgarian agriculture was made possible by the transition to the cultivation of more competitive species of plants and animal species, the expansion of the scope of advanced agricultural technologies, the promotion of modern and sustainable agricultural production, which was a prerequisite for the protection of the environment and the use of biotechnology.

Conclusions of the study and prospects for further exploration in this direction. As the experience of the first over ten years of Bulgaria's stay in the European Union shows, Bulgarian agricultural producers could not objectively withstand the pressure of a more developed European economy, which, moreover, was subsidized at a much higher level. Bulgaria is a promising EU partner enough to create a FTA. The agricultural complex of Bulgaria was one of the important motivating places for the EU to conclude an in-depth FTA between Bulgaria and the European Union. Ukraine had rich natural resources and human capital as well as historical agrarian production traditions, and it directly borders the EU.

\footnotetext{
${ }_{7}^{7}$ Башев Х. Ефекти от прилагане на европейски политики вїрху земеделските стопанства в Р. България. София : ИАИ, 2018. С. 212.

${ }^{8}$ Онищенко О., Осташ Т. Аграрні перетворення в країнах Центральної та Східної Європи. Економіка України. 1994. № 8. С. 30.
} 
Among the competitive factors of the Bulgarian agroindustrial complex are the natural advantages in the production of certain types of agricultural products (vegetables, oilseeds, berry crops and fruits, etc.) for domestic and foreign markets. Bulgaria, unlike the EU, did not have a clear, contemporary challenge to the agro-industrial policy challenges and threats. In the long term, this factor will have a significant negative impact on the competitive position of the Bulgarian agricultural sector in the world and will increase the vulnerability of agriculture to external and internal influences. At the same time, the Bulgarian authorities should take into account the growing risks of reducing the competitiveness of the Bulgarian agroindustrial complex as a result of the liberalization of relations with the EU due to the increased efficiency of the EU agricultural sector as a result of the reform of the CAP. In the future, the problems of compliance of the standards of safety and quality of agricultural products with the WTO requirements and their harmonization with the laws, norms and standards of the EU will become more and more urgent for Bulgaria, which will open up access to markets for Bulgaria and provide significant foreign direct investment. Bulgaria has had the opportunity to influence the developed countries, in particular the EU, as a leading player in the global agricultural market, with the aim of eliminating export subsidies for agricultural products.

This requirement could be put forward to the EU in the context of discussing the conditions of access to agricultural markets of Bulgaria for EU agricultural products. However, there was a risk that farmers' lobbying would leave direct payments in force. New EU member states will require a new method of recalculating direct payments between EU countries, in order to avoid unreasonably large differentiation in the redistribution of the general budget in favor of old EU members. The period of adaptation of Bulgaria's national agriculture to the requirements of the EU's CAP will be quite long and will obviously be accompanied by some losses and, in some cases, by the decline of rural areas. That is why a reasonable program of adaptation of the Bulgarian agrarian sector to the EU requirements and strengthening the role of the state in securing its implementation and support of the agroindustrial complex through the forms and channels used by the member states of the world and European trade and economic unions are needed.

Given the increased economic risks of international trade with Russia, Bulgarian farmers have a great need to adapt and search for new markets. The practical implementation of these intentions is now possible through the full FTA Agreement with the EU. Bulgaria's accession to the EU accelerated the development and implementation of the new agricultural policy, intensified control over its implementation in the agro-development management system, facilitated the attraction of internal and external investments, ensured the state's participation in the development of the provisions of the Common Agricultural Policy and rules of international trade in agricultural products.

\section{References:}

1. Анастасова М. Миграционните процеси на населението в Р. България при прехода към пазарна икономика. София : Издателство на институт по икономика на селското стопанство, 2015. 830 с. 


\section{Проблеми сучасності}

2. Башев X. Ефекти от прилагане на европейски политики вїрху земеделските стопанства в Р. България. София : ИАИ, 2018. 378 с.

3. Вачков Д. Българският външен дълг: Банкрутът на комунистическата икономика. София : Институт за изследване на близкото минало, 2009. 456 с.

4. Вачков Д. НРБ от началото до края. София : Институт за изследване на близкото минало, 2011. 480 с.

5. Иванов Б. Устойчивост в земеделието. София : Авангард Прима, 2009. 230 с.

6. Маслоу Е. Мотивация и личность. София : Кибея, 2001. 296 с.

7. Назаренко В. Аграрная политика Европейского Союза / Институт Европы РАН. Москва : ООО «Маркет ДС Корпорейшн», 2004. 11362 с.

8. Натан И. Икономика на България. София : Наука и изкуство, 2013. 171 с.

9. Онищенко О., Осташ Т. Аграрні перетворення в країнах Центральної та Східної Європи. Економіка України. 1994. № 8. С. 9.

10. Пенков И. Икономическа география на България. София : Наука и изкуство, 2008. $422 \mathrm{c}$.

11. Русчева Д. Продоволствените ресурси на България при осъществяване на Общата селскостопанска политика на ЕС. София : Унив. изд. «Св. Климент Охридски», 2010. 151 с.

12. Трейси Майкл. Сельское хозяйство и продовольствие в экономически развитых странах. Введение в теорию, практику, политику. Санкт-Петербург : Экономическая школа, 1995. $431 \mathrm{c}$.

13. Тютюнджиев И. Стопанска история на България. София : Ровита, 2011. 204 с.

14. Nukamp P., Poot J. Spatial Perspectives on New Theories of Economic Growth. Annals of Regional Science. 1998. № 32 (1). P. 7-37. 